\title{
PENDIDIKAN KARAKTER DI SEKOLAH
}

\author{
Edi Rohendi*)
}

\begin{abstract}
Abstrak
Pendidakan karakter tiba-tiba menjadi wacana hangat di dunia pendidikan IndonesiWa laupun gagasan ihwal karakter adalah gagasan tua setua sejarah pendidikan, namun kemunculan gagasan "pendidikan karakter "(character building)menginterupsi bangsa kita khususnya yang sedang melanda bangsa Indonesia. Masalah-masalah yang terjadi seperti kekerasan, korupsi, manipulasi, praktek-praktek kebohongan dalam dunia pendidikan mulai dari menyontek dalamujian sampai plagiat,kurang keteladanan dikalangan para pemimpin bangsa, dan sebagainya, sebenarnya menyangkut masalah karakter. Walaupun sudah terlambat dalam menerapkan pendidikan karakter disekolah, "But late than never", masih banyak generasi kita para peserta didik yang duduk dibangku sekolah dan butuh pendidikan karakter agar dimasa depannya menjadi orang yang tidak hanya cerdas secara intelek tapi juga memiliki karakter. Dunia pendidikan diharapkan menjadi motor penggerak sebagaimana telah dikemukakan oleh Mendinas Muhammad Nuh dalam peringatan Hardiknas tahun 2010 yang lalu bahwa “ Pembangunan dan Pendidikan Karakter menjadi keharusan karena pendidikan tidak hanya menjadikan peserta didik cerdas. Pendidikan juga untuk membangun budi pekerti dan sopan santun dalam kehidupan “. Batasan karakter berada dalam dua wilayah.Ia diyakiniada sebagai sifat fitri manusia, sementara pada sisi lain ia diyakini harus “dibentuk"melalui pendidikan, salah satunya melalui pendidikan karakter disekolah. Pelaksanaan Pendidikan karakter disekolah sebagai alternative dikemukakan dalam makalah ini adalah : melalui Pembidanan dengan formula $4 \mathrm{M}$ (mengetaqhui, mencintai, menginginkan dan mengerjakan, juga dengfan metode pembiasaan . Selain itu melalui metode : mengajarkan, keteladanan, mmenentukan prioritas dan praksis prioriotas.
\end{abstract}

Kata Kunci : Pendidikian Karakter, pendidikan Akhlak dan pendidikan Moral.

\section{A. Pendahuluan}

Pendidikan karakter adalah pendidikan untuk "membentuk kepribadian sesorang melalui pendidikan budi pekerti, yang hasilnya terlihat dalam tindakan nyata seseorang, yaitu tingkah laku yang baik, jujur, bertanggung jawab, menghormati hak orang lain, kerja keras dan sebagainya. (Thomas Lickona, 1991).

Tema peringatan Hari pendidikan nasional tahun 2010 yang baru lalu dicanangkan oleh Mendiknas Muhammad Nuh adalah :’Pendidikan karakter untuk membangun Peradaban Bangsa”. Beliau mengatakan Pembangunan Karakter dan 
Pendidikan Karakter menjadi keharusan karena pendidikan tidak hanya menjadikan peserta didik cerdas, pendidikan juga untuk membangun budi pekerti dan sopan santun dalam kehidupan. Untuk merealisasikan tema tersebut lebih lanjut mendiknas mengemukakan pendidikan karakter akan diterapkan pada semua jenjang pendidikan mulai jenjang pendidikan SD sampai Perguruan Tinggi, namun porsinya akan lebih besar diberikan pada Sekolah Dasar (SD). Pendidikan karakter harus dimulai sejak dini yakni SD porsinya mencapai 60 \% dibandingkan dengan jenjang pendidikan lainnya. Hal ini agar mudah diajarkan dan melekat dijiwa anak-anak itu hingga kelak ia dewasa. Lebih jauh Mendiknas menyatakan pada saat menjadi pembicara pada seminar Nasional "Pendidikan Karakter bangsa “ pada rapat pimpinan Program Pasca Sarjana LPTK seluruh Indonesia di Universitas negeri Medan "Pendidikan karakter harus dimulai dari SD karena jika karakter tidak terbentuk sejak dini maka akan susah untuk merubah karakter seseorang”.

Dunia pendidikan diharapkan sebaga motor penggerak untuk m emfasilitasi pembangunan karakter, sebab apa-apa yang terjadi dimasyarakat kita sebenarnya menyangkut masalah karakter, seperti kekerasan, korupsi, manipulasi , kebohongankebohongan dan perilaku menyimpang lainnya ,berangkat dari pendidikan. Oleh sebab itu melalui pendidikan pula karakter bangsa dapat diperbaiki dan dibentuk terutama Pembangunan karakter dan pendidikan mulai dari usia dini. Pembangunan karakter dan pendidikan karakter menjadi suatu keharusan karena pendidikan tidak hanya menjadikan peserta didik cerdas, juga mempunyai budi pekerti dan sopan santun sehingga keberadaannya sebagai anggota masyarakat menjadi bermakna baik bagi dirinya maupun orang lain.

\section{B. Prinsip-Prinsip Pendidikan Karakter}

Ada beberapa prinsip dalam pendidikan karakter yakni Pertama, manusia adalah makhluk yang dipengaruhi dua aspek, pada dirinya memiliki sumber kebenaran dan pada luar dirinya ada dorongan atau kondisi yang memengaruhi kesadaran.

Kedua, karena menganggap bahwa perilaku yang dibimbing oleh nilai-nilai

utama sebagi bukti dari karakter, pendidikan karakter tidak meyakini adanya pemisahan antara roh, jiwa, dan badan. Hadis Rosulullah menyatakan bahwa iman dibangun oleh perasaan serta roh, jiwa dan badan, yaitu melalui perkataan, keyakinan, dan tindakan. Tanpa tindakan semua yang diucapkan dan diyakini bukanlah apa-apa tanpa keyakinan maka tindakan dan perkataan tidak memiliki makna, kemudian tanpa pernyataan dalamperkataan tindakan dan keyakinan tidak akan terhubung. 
Ketiga, pendidikan karakter mengutamakan munculnya kesadaran pribadi peserta didik untuk secara ikhlas mengutamakan karakter positif. Setiap manusia memiliki modal dasar (potensi yang membedakan dirinya dengan orang lain. Aktualisasi dari kesadaran ini dalam dunia pendidikan adalah pemupukan keandalan khusus seseorang yang memungkinkannya memiliki daya tahan dan daya saing dalam perjuangan hidup.

Keempat, pendidikan karakter mengarahkan peserta didik untuk menjadi manusia ulul albab yang tidak hanya memiliki kesadaran diri, tetapi juga kesadaran untuk terus mengembangkan diri, memperhatikan masalah lingkungan, dan memperbaiki kehidupan sesuai dengan pengetahuan dan karakter yang dimilikinya. Manusia ulul albab adalah manusia yang dapat diandalkan dari segala aspek, baik aspek intelektual , afektif, maupun spiritual.

\section{Pendidikan Karakter Dan Pendidikan Akhlak}

Secara historis pendidikan karakter merupakan misi utama para Nabi. Rosulullah Muhammad saw. Punya misi utama diutus kemuka bumi “ Liutammima makarim al akhlaq” yakni untuk menyempurnakan akhlak (karakter). Hal ini mengindikasikan bahwa pembentukan karakter merupakan kebutuhan utama bagi tumbuhnya cara beragama yang dapat menciptakan peradaban. Agama hadir sebagai jalan untuk menyempurnakan karakter. Dalam sejarah dikenal ketika Al Quran turun dibawa oleh Nabi Muhammad ditengah karakter bangsa Arab yang rusak . Al Quran sebagai buku ajar yang menghadapi peserta didik yakni masyarakat Arab jahiliyah itu.Melalui Al Quran secara perlahan dan bertahap serta pasti, karakter itu dibentuk kedalam prinsip-prinsip ketundukkan, kepasrahan, serta kedamaian (makna dasar Islam ). Dimulai dari perintah membaca (iqro), karakter Islam dibentuk, kemudian perlahan-lahan diingatkan untuk "bangun dari berselimut”, menghayati pergantian alam semesta, berkontemplasi pada malam hari , menghargai sesuatu sesuai dengan kodratnya (warobbuka fakbbir), dan membersihkan perilaku (wasiyabaka fatohhir). Pembentukan karakter begitu memenuhi materi-materi awal Al Quran, bahkan perintah ritual ibadah ( seperti sholat, saum,zakat dan haji ) dikaitkan dengan

tumbuhnya karakter yang baik. Bahkan ritual ibadah dianggap sia-sia apabila tidak didukung oleh ibadah sosial yang muncul sebagai wujud karakter yang positif. Menurut pandangan agama islam dianggap orang yang bangkrut, atau failit, atau jatuh miskin (muflis). 


\section{Pendidikan Akhlak, Pendidikan Karakter dan Pendidikan Moral 1. Pendidikan Akhlak}

Pendidikan akhlak sebagaimana dirumuskan oleh Ibnu Maskawih, merupakan upaya kearah terwujudnya sikap batin yang mampu mendorong secara spontan lahirnya perbuatan-perbuatan yang bernilai baik dari seseorang. Dalam pendidikan akhlak ini kriteria benar dan salah untuk menilai perbuatan yang muncul merujuk pada Al Quran dan Assunah sebagai sumber tertinggi ajaran Islam.Lebih lengkapnya Ibnu Maskawih menyatakan "Akhlak adalah Keadaan jiwa seseorang yang mendorongnya untuk melakukan perbuatan-perbuatan tanpa melalui pertimbangan pikiran lebih dulu”. Dengan demikian pendidikan akhlak bisa dikatakan sebagai pendidikan moral dalam diskursus pendidikan islam. Dari telaah konsep akhlak yang dikemukakan oleh tokoh-tokoh pendidikan akhlak seperti Ibnu Maskawih, al Gazali, Ahmad Amin, Ibnu Sina, menunjukkan bahwa tujuan puncak pendidikan akhlak adalah terbentuknya karakter positif dalam perilaku anak didik. Karakter positif ini tiada lain adalah penjelmaan sifat-sifat mulia Tuhan dalm kehidupan manusia, yakni ál asmaul husna”.

\section{Pendidikan Karakter}

Penddidikan karakter mulai ramai dibicarakan sejak tahun 1990 an . Thomas Lickona dianggap sebagai pengusungnya melalui karyanya yaitu " The Return of Character Education” sebuah buku yang menyadarkan dunia Barat bahwa pendidikan karakter adalah sebuah keharusan. Karakter sebagaimana didefinisikan oleh Ryan dan Bohlin, mengandung tiga unsure pokok, yaitu mengetahui kebaikan (Knowing the good),mencintai kebaikan ( loving the good), dan melakukan kebaikan ( doing the good).

Dalam pendidikan karakter kebaikan sering kali dirangkum dalam sederet sifat-sifat baik . Pendidikan karakter adalah sebuah upaya untuk membimbing perilaku manusia menuju stndar-standar baku. Upaya ini juga memberi jalan untuk menghargai persepsi nilai -nilai pribadi yang ditampilkan disekolah.Fokus pendidikan karakter adalah pada tujuan etika, tetapi prakteknya meliputi penguatan kecakapan-kecaakapan yang penting yang mencakup perkembangan sosial siswa. Pendidikan karakter bukan hanya mengajarkan mana yang benar dan mana yang salah, tetapi lebih dari itu menanamkan kebiasaan (habituation) tentang yang baik sehingga siswa didik menjadi faham, mampu merasakan, dan mau melakukannya. Kaarakter adalah tabeat seseorang yang langsung di-drive oleh otak.

\section{Pendidikan Moral}

Pendidikan moral (moral education) secara umum digunakan untuk menjelaskan penyelidikan isu-isu etika diruang kelas dan sekolah dan sifatnya lebih 
umum . Isu-isu etika disini cenderung pada penyampaian nilai-nilai yang benar dan nilai-nlai yang salah, tetapi aplikasinya dalam kehidupan tidak mendapat porsi yang memadai. Moral ini sangat normative dan kurang bersinggungan dengan ranah afektif dan psikomotorik.

\section{E. Pelaksanaan Pendididikan Karakter di Sekolah}

Pelaksanaan Pendidikan karakter di sekolah yang dikemukakan oleh para ahli pendidikan karakter dikemukakan berbagai cara atau metode adalah bahwa Pertama, menggunakan metode pembidanan. Socrates dalam Ratna Megawangi mengemukakan perlunya formula $4 \mathrm{M}$ dalam pendidikan karakter ,yaitu: Mengetahui (knowing the good), mencintai ( loving the good), mengingin kan (desiring the good), dan mengerjakan (acting the good) kebaikan secara simultan dan berkesinambungan. Cara ini menunjukkan bahwa karakter adalah sesuatu yang dikerjakan berdasarkan kesadaran yang utuh. Sedan gkan kesadaran utuh itu adalah sesuatu yang diketahui secaara sadar, dicintainya,dan diinginkan. Dari kesadaran utuh ini, barulah tindakan dapat menghasilkan karakter yang utuh pula. Proses pengajaran yang bermula dari memberikan pengetahuan peserta didik tentang kebaikan, menggiring atau mengkondisikan agar peserta didik mencintai kebaikan tersebut, kemudian membangkitkan peserta didik agar menginginkan karakter yang diajarkan, dan terakhir mengondisikan peserta ddidik agar mengerjakan kebaikan secara sukarela, simultan dan berkesinambungan.

Kedua, metode atau dengan cara pembiasaan. Pembiasaan merupakan alat penddidikan. Daalam pembiasaan peserta didik dipancing untuk menyadari karakter tertentu yang telah ditentukan, baru kemudian karakter yang telah disadari dan diinginkan itu dibiasakan dalam keseharian. Pembiasaan dimulai dengan menetapkan sikap atau tingkah laku atau karakter yang baik kemudian dilatihkan dan dibiasakan kepada peserta didik. Secara berproses, latihan-latihan yang dilakukan apabila diikuti dengan kesadaran dan mawas diri, lama kelamaan akan menyatu dalam kepribadian peserta didik dan itu menjadi karakter. Kebiasaan tersebut haarus dilestarikan sehingga mempribadi atau menyatu dalam kehidupan peserta didik.

Kemudian dalam pelaksanaan pendidikan karakter di sekolah Doni A. Koesoema dalam Bambang Q-Anees (2008), mengajukan lima metode atau lima cara pendidikan karakter yaitu :

\section{Mengajarkan}

Mengajarkan karakter berarti memberikan pemahaman pada peserta didik tentang struktur nilai tertentu, keutamaan (bila dilaksanakan), maslahatnya, manfaatnya, kegunaannya, kerugiannya atau bahayanya (bila tak dilaksanakan). 
Mengajarkan nilai-nilai memiliki dua faedah. Pertama, memberikan pengetahuan konseptual baru. Kedua, menjadi pembanding atas pengetahuan yang telah dimiliki oleh peserta didik, karena proses mengajarkan tidaklah menolong, melainkan melibatkan peserta didik. Inilah unsur metode pendidikannya.

Dalam konsep mengajarkan ini yaitu memberikan kesempatan kepada peserta didik untuk mengajukan apa yang difahaminya, apa yang pernah dialaminya, dan bagaimana perasaannya berkenaan dengan konsep yang diajarkan. Melalui cara ini, konsep yang diajarkan bukanlah sesuatu yang asing dan baru melainkan sudah dialami atau pernah teramati oleh peserta didik. Konsep tetap diberikan dan menjadi otoritas guru. Konsep yang diberikan guru dapat bermanfaat bagi peserta didik bukan sebagai doktrin melainkan sebagai norma-norma bagi apa yang telah dialami peserta didik. Dalam mengajarkan konsep-konsep ini disertai dengan contoh-contoh yang pernah dan teramati oleh peserta didik.

\section{Keteladanan}

Keteladanan adalah alat utama dalam pendidikan . Hal ini dipraktekan oleh Rosulullah Muhammad saw. dalam mendidik umatnya. Firman Allah menyatakan "Laqod kana lakum fi rosulillah uswatun hasanah" artinya "Sungguh telah ada pada diri Rosulullah contoh tauladan yang baik” (Q.S.Al Ahzab: 21). Dalam pendidikan karakter, keteladanan perlu dikembangkan oleh orang tua dilingkungan keluarga, guru-guru disekolah, tokoh masyarakat dan ulama serta para pemimpin bangsa. Peribahasa mengatakan "Bahasa tingkah laku (keteladanan) lebih mantap ketimbang bahasa ucapan. Dawah bila hal lebih baik dengan dawah bil qaul. Guru harus terlebih dahulu memilki karakter yang hendak diajarkan, guru adalah yang digugu dan ditiru (digugu ucapannya dan ditiru perilakunya). Peserta didik akan meniru apa yang dilakukan gurunya.

Keteladanan tidak hanya bersumber dari guru disekolah, tapi dari seluruh tenaga keependidikan lainnya yang ada dilembaga sekolah mulai dari kepala Sekolah, stap tata usaha, administrasi, kepustakaan, dimana peserta didik berada dan sering berhubungan. Oleh sebab itu pendidikan karakter membutuhkan lingkungan pendidikan yang utuh.

\section{Menentukan Prioritas}

Penentuan prioritas harus ditentukan agar proses evaluasi atas berhasil tidaknya pendidikan karakter dapat menjadi jelas. Tanpa prioritas, pendidikan karakter tidak dapat terfokus dan karenanya tidak daapat dinilai berhasil atau tidak berhasil. Lembaga sekolah memilki beberapa beberapa kewajiban :

Pertama, menentukan tuntutan standar yang akan ditawarkan pada peserta didik. Kedua, semua pribadi yang terlibat dalam lembaga pendidikan harus 
memahami secara jernih apa nilai yang ingin ditekankan dalam lembaga pendidikan karakter. Ketiga, jika lembaga ingin menetapkan perilaku struktur yang menjadi ciri khas lembaga, maka karakter standar itu harus difahami oleh anak didik.

\section{Praksis Prioritas}

Lembaga pendidikan harus mampu membuat verifikasi sejauh mana prioritas yang telah ditentukan telah dapat direalisasikan dalam lingkup pendidikan melalui berbagai unsur yang ada dalam lembaga pendidikan ini.

\section{Refleksi}

Refleksi disini berarti dipantulkan kedalam diri. Apa yang telah dialami masih tetap terpisah dengan kesadaran diri sejauh ia belum dikaitkan, dipantulkan dengan isi kesadaran seseorang. Refleksi disini merenungkan apa-apa yang telah dipelajarinya. Refleksi disini dapat juga disebut sebagai proses bercermin, mematut matutkan diri pada peristiwa / konsep yang telah dialami, apakah saya seperti itu? Apakah ada karakter baik seperti itu pada diri saya?

Selain metode-metode tersebut diatas, dalam pendidikan karakter disekolah ada lagi sebagai alternative metode dialog partisipatif, dan metode eksperimen. Metode dialog partisipatif mendorong para siswa untuk kreatif, kritis,mandiri, dan terampil berkomunikasi. Metode dialog partisipasi dijabarkan /dikonkritkan dalam kegiatan-kegiatan seperti diskusi kelompok, sharing pengalaman keseharian dan sharing pengalaman iman, wawancaara, dramatisasi, dinamika kelompok dan sebagainya. Metode naratif menggunakan cerita sebagai model pengembangan diri. Metode ini dianggap unggul karena bersifat merangsang imajinasi peserta didik, menyapa peserta didik secara menyeluruh, baik segi kognitif maupun afektif, bersifat menawarkan, membebaskan dan tidak menjejali.

\section{F. Kesimpulan}

Pendidikan karakter merupakan misi utama para Nabi. Muhammad Rasulullah sedari awal tugasnya memiliki suatu pernyataan yang unik, bahwa dirinya diutus untuk menyempurnakan akhlak (karakter). Manifesto Muhammad Rasulullah ini mengindikasikan bahwa pembentukan karakter merupakan kebutuhan utama bagi setiap manusia lebih-lebih bagi peserta didik di sekolah mulai dari usia dini. Pada sisi lain masing-masing manusia telah memiliki karakter tertentu, namun perlu disempurnakan.

Pentingnya pendidikan karakter di sekolah sebagai tempat mendidik generasi penerus bangsa, hal ini berangkat dari kondisi objektif dalam kehidupan masyarakat Indonesia saat ini telah terjadi penyimpangan-penyimpangan seperti kekerasan, korupsi, manipulasi, kebohongan-kebohongan, tidak adanya panutan dan keteladanan 
dikalangan para pemimpin, kepalsuan, pelanggaran dan pemutar balikan hokum, dan sebagainya. Hal ini mendorong dunia pendidikan untuk membentuk dari awal peserta didik sebagai manusia yang masih bersih untuk diberikan pendidikan karakter, walaupun sudah terlambat, tetapi lebih baik daripada tidak dimulai.

Adapun pelaksanaan pendidikan karakter di sekolah dilakukan dengan berbagai metode yang dapat dilakukan oleh guru atau lembaga pendidikan yaitu: Metode pembidanan yang diformulasikan melalui 4M, yaitu Mengetahui kebaikan (knowing the good), Mencintai kebaikan (loving the good), Menginginkan kebaikan (de siring the good), dan Mengerjakan kebaikan (acting the good). Selain metode tersebut, metode pendidikan karakter dilakukan melalui metode: Mengajarkan, Keteladanan, Menentukan prioritas, praksis prioritas, metode dialog partisifatifdan eksperimen serta Metode naratif.

\section{Daftar Pustaka}

Akhmad Tafsir, (2008), Pesan Moral Ajaran Islam, Maestro, Bandung. Asri Budiningsih C., (2004), Pembelajaran Moral, Rineka Cipta, Jakarta. Alsyaiban, (1979), Falsafah Pendidikan Islam, Bulan Bintang, Jakarta. Bambang Q-Anees, Adang Hambali, (2008), Pendidikan Karakter Berbasis Al Quran, Simbiosa Rekatama Media, Bandung.

Din Zaenudin, (2004), Pendidikan Budi Pekerti Dalam Perspektif Islam, Almawardi Prima, Jakarta.

Doni A. Koesoema, (2007), Tiga Matra Pendidikan Karakter, Basis.

Humaidi Tatapangarsa, (1979), Pengentar Kuliah Akhlak, Bina Ilmu, Surabaya.

*) Edi Rohendi adalah dosen Prodi PGSD Universitas Pendidikan Indonesia Kampus Cibiru. 